\title{
Quinolinate in Brain and Cerebrospinal Fluid in Rat Models of Congenital Hyperammonemia
}

\author{
MICHAEL B. ROBINSON, MELVYN P. HEYES, NORIFUSA J. ANEGAWA, EILEEN GORRY, \\ SINA DJALI, E. DAVID MELLITS, AND MARK L. BATSHAW
}

\begin{abstract}
The Children's Seashore House, Children's Hospital of Philadelphia [M.B.R., N.J.A., E.G., S.D., M.L.B.] and the Departments of Pediatrics [M.B.R., N.J.A., E.G., S.D., M.L.B.], Pharmacology [M.B.R.], and Neurology [M.L.B.], University of Pennsylvania School of Medicine, Philadelphia, Pennsylvania 19104; National Institute of Mental Health. Bethesda. Maryland 20892 [M.P.H.J; and Department of Neurology, Johns Hopkins University,
\end{abstract} Baltimore, Maryland 21205 [E.D.M.]

\begin{abstract}
Children with inborn errors of urea synthesis who survive neonatal hyperammonemic coma commonly exhibit cognitive deficits and neurologic abnormalities. Yet, there is evidence that ammonia is not the only neurotoxin. Hyperammonemia appears to induce a number of neurochemical alterations. In rodent models of hyperammonemia, uptake of L-tryptophan into brain is increased. It has been reported that in an experimental rat model of hepatic encephalopathy, in the ammonium acetate-injected rat, and in patients with hepatic failure and inborn errors of ammonia metabolism, quinolinate, a tryptophan metabolite, is increased. Elevations in quinolinate are of particular concern, as quinolinate could excessively activate the $\mathbf{N}$ methyl-D-aspartate subclass of excitatory amino acid receptors, thereby causing selective neuronal necrosis. We sought to identify an animal model that would replicate the increases in quinolinate that have been associated with hyperammonemia in humans. Levels of quinolinate were measured in hyperammonemic urease-infused rats and ammonium acetate-injected rats. In the urease-infused rat, brain tryptophan was doubled, and serotonin and its metabolite 5-hydroxyindoleacetic acid were significantly increased. Yet, despite the increase in tryptophan and evidence for increased metabolism of tryptophan to serotonin, there were no observed increases of quinolinate in brain, cerebrospinal fluid, or plasma. In the ammonium acetateinjected rat, significant increases of 5-hydroxyindoleacetic acid in cerebral cortex were also observed, but quinolinate did not change in cerebrospinal fluid or cerebral cortex. In summary, we were unable to demonstrate an increase of quinolinate in brain or cerebrospinal fluid in these rat models of hyperammonemia. (Pediatr Res 32: 483-488, 1992)
\end{abstract}

Abbreviations

CSF, cerebrospinal fluid

5-HIAA, 5-hydroxyindole acetic acid

NMDA, N-methyl-D-aspartate

QUIN, quinolinate

Trp, tryptophan

Received October 18, 1991; accepted May 12, 1992.

Correspondence and reprint requests: Michael B. Robinson, Children's Hospital of Philadelphia, Room 7159, 34th St. and Civic Center Blvd., Philadelphia, PA $19104-4399$.

Supported by ROI-NS28033 and MRRC P30-HD-26979. M.B.R. is an Alfred P. Sloan Fellow.
The most common causes of symptomatic hyperammonemia in children are congenital urea cycle disorders and organic acidemias. Affected children present with episodes of vomiting, lethargy, and coma either in the newborn period or in early childhood, depending on the severity of the enzyme deficiency (1). Despite treatment, the majority of children have cognitive deficits and other neurologic impairments (2). Although the mechanism of brain damage induced by hyperammonemia is not clear, it is known that the degree of brain damage correlates with the duration of hyperammonemic coma rather than peak plasma ammonia level (2), suggesting that ammonia may be acting through a secondary neurotoxin in a time-influenced fashion.

In certain animal models and humans with hyperammonemia induced by portal systemic encephalopathy, the level of the Trp metabolite, QUIN, has been found to be elevated in brain and CSF $(3,4)$. This observation is noteworthy because QUIN is an agonist at the NMDA subclass of excitatory amino acid receptors. It is well documented that excessive activation of NMDA receptors results in specific degeneration of the neurons that express these receptors $(5,6)$.

It has been reported previously that children with urea cycle disorders have increased levels of Trp and the serotonin metabolite 5-HIAA in CSF and that this elevation is associated with behavioral alterations, such as decreased food intake and altered sleep patterns $(7,8)$. Because Trp is a precursor for both 5-HIAA and QUIN (Fig. 1), we hypothesized that QUIN might be elevated in congenital hyperammonemias, as it is in portal systemic encephalopathy. In fact, we have documented increases of QUIN in CSF of children with congenital hyperammonemia (11). In this study, we attempted to provoke elevations in QUIN in two animal models of acute hyperammonemia: the urease-infused rat (12) and the ammonium acetate-injected rat.

\section{MATERIALS AND METHODS}

Animal Preparations. Male Sprague-Dawley rats weighing 250-300 g were placed in individual cages on $12 \mathrm{~h}$ light $/ 12 \mathrm{~h}$ dark cycles for a 5-d acclimatizing period. They had free access to pellets prepared from an L-amino acid mixture (U.S. Biochemical Corp., Cleveland, $\mathrm{OH}$ ) (13); the mixture contained, in $\mathrm{g} / \mathrm{kg}$ pellets, Ala 3.5, Arg 11.2, Asn 6.0, Asp 3.5, Cys 3.5, Glu 35.0, Gly 23.3, His 3.3, Ile 8.2, Leu 11.1, Lys 14.4, Met 8.2, Phe 11.6, Pro 3.5, Ser 3.5, Thr 8.2, Trp 1.75, Tyr 3.5, and Val 8.2. This mixture also contained vitamin supplements and a salt mixture and had a caloric content of $4.4 \mathrm{kcal} / \mathrm{g}$. This diet was used because it contains an essential amino acid mixture that is very similar to that used to treat children with congenital hyperammonemia (1). 


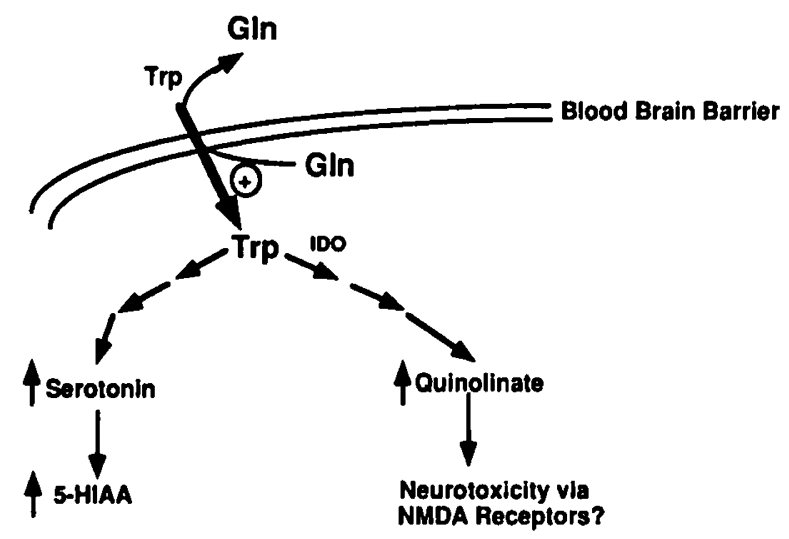

Fig. 1. Schematic illustration of the potential effects of hyperammonemia on Trp metabolism to serotonin, 5-HIAA, and QUIN (quinoli"lal('). Hyperammonemia results in increased levels of brain glutamine $(G / n)$, potentially resulting in increased transport of Trp and other large nonpolar amino acids into brain via an antiport mechanism $(9,10)$. Increases in Trp transport could lead to increased synthesis of serotonin/ 5-HIAA and QUIN. Indoleamine-2,3-dioxygenase (IDO) mediates the first enzymatic step in Trp oxidation to QUIN.

An osmotic minipump (Alzet 2001, Alza, Palo Alto, CA) was then implanted intraperitoneally under halothane or pentobarbital anesthesia. The minipump contained Jackbean urease (type VII, Sigma Chemical Co., St. Louis, $\mathrm{MO}$ ) in sterile $\mathrm{NaCl} 0.9 \%$, providing an infusion rate of $50 \mu \mathrm{M}$ units $/ 100 \mathrm{~g}$ body weight/d ( $1 \mu \mathrm{M}$ unit is the amount of enzyme required to produce $1 \mu \mathrm{mol}$ of $\mathrm{NH}_{3}$ per min from urea at $\mathrm{pH} 7.0$ and at $25^{\circ} \mathrm{C}$ ). A paired group of animals received sham operations. After surgery, the animals were returned to the complete amino acid mix.

In the first study, the animals were killed 12,24 , or $48 \mathrm{~h}$ after implantation to determine the timed effect of urease on amino acids, biogenic amines, and QUIN. The animals were decapitated in a nonfasting state, and the brains were dissected within $2 \mathrm{~min}$ on a cooled plate (14). The cortex of one hemisection was dissected for analysis of QUIN and the other hemisphere for biogenic amines and amino acids. All brain samples were stored at $-70^{\circ} \mathrm{C}$ until the analyses were performed.

In the second study, animals were given an intraperitoneal injection of $\operatorname{Trp}(50$ or $200 \mathrm{mg} / \mathrm{kg}$ ) or saline $46 \mathrm{~h}$ after urease or sham implantation. Two h later blood, CSF, and brain tissue were obtained for analyses.

In the third study, animals received intraperitoneal injections of ammonium acetate $(7 \mathrm{mmol} / \mathrm{kg}$ ) or an equivalent volume (1 $\mathrm{mL} / \mathrm{kg}$ ) of sodium acetate or saline $(0.9 \%)$. Solutions were made up in sterile saline and neutralized. CSF, blood, and brain tissue were obtained for analyses at $1 \mathrm{~h}$ after injection with ammonium acetate, sodium acetate, or saline. CSF samples were obtained from the cisterna magna $10 \mathrm{~min}$ after the animals were anesthetized with pentobarbital $(50 \mathrm{mg} / \mathrm{kg})$ (15). All animal experimentation was performed in accordance with the highest possible standards of humane care and was approved by the Institutional Animal Care and Use Committee.

Biochemical Measures. Ammonium, amino acids, and biogenic amines. Before the rats were killed, heparinized blood was obtained by tail vein puncture. To prevent the generation of ammonia in vitro, the blood was precipitated with perchloric acid and centrifuged, and the supernatant was neutralized with $\mathrm{KOH}(16)$. After centrifugation, the supernatants were assayed for ammonium by a microfluorometric adaptation of a glutamate dehydrogenase method $(12,17)$. The brain tissues were homogenized (diluted $1: 5$ ) in a $0.1 \mathrm{~N}$ sodium acetate buffer, $\mathrm{pH} 4.95$. Amino acids in brain were measured after precipitation with $5 \%$ sulfosalicylic acid by automated ion exchange chromatography using a Beckman 6300 high pressure amino acid analyzer. For all studies except those presented in Table 1, Trp was measured separately using an adaptation of an HPLC method with fluo- rometric detection using a Kratos flow-through fluorometer (Kratos Analytical Instruments, Ramsey, NJ) with a 254-nm excitation filter and $340-\mathrm{nm}$ emission cutoff filter and an FSA 113 excitation lamp (Kratos Analytical Instruments) (18). The mobile phase consisted of a sodium acetate $(50 \mathrm{mM})$ with disodium EDTA $(50 \mu \mathrm{M})$ adjusted to $\mathrm{pH} 3$ with phosphoric acid. Acetonitrile was added to a $8 \%$ final concentration. The flow rate was $1.0 \mathrm{~mL} / \mathrm{min}$. For the results presented in Table 1 , a McPherson FL-750 fluorometer set at $301 \mathrm{~nm}$ excitation with a 320-nm emission cutoff filter was used to measure Trp.

Biogenic amines and 3-hydroxykynurenine in brain were determined by an adaptation of a reverse phase HPLC method with electrochemical detection (ESA EC detector, Coulochem model $5100 \mathrm{~A}$, ESA, Bedford, MA) set at $0.45 \mathrm{~V}$ and a $\mathrm{Cl} 18$ reverse phase column (Brownlee Labs, Santa Clara, CA) (19). The mobile phase consisted of sodium acetate $(50 \mathrm{mM})$, disodium EDTA (0.05 $\mathrm{mM}$ ), and heptane sulfonate (Kodak) $2 \mathrm{mM}$, which was adjusted to $\mathrm{pH} 4$ with phosphoric acid. Acetonitrile was added to a $6 \%$ final concentration. The flow rate was 1.0 $\mathrm{mL} / \mathrm{min}$. Brain tissue (diluted 1:20) was homogenized in a 0.1 $\mathrm{N}$ sodium acetate buffer, $\mathrm{pH}$ 4.95. Ascorbate oxidase (1700 units/ $\mathrm{mg}$, Sigma Chemical Co.) $6.7 \mu \mathrm{g} / \mathrm{mL}$ was added to the homogenates to eliminate the ascorbate front.

Quinolinic acid. QUIN measurements were made in a blinded fashion by one investigator (M.P.H.) using electron capture negative chemical ionization mass spectrometry and gas chromatography $(20,21)$. The high sensitivity of this method (minimum detectability of $\leq 50 \mathrm{fg}$ ) allows quantification of QUIN at a signal to noise ratio of $>20: 1$, without the need for pooling of brain samples from different animals. QUIN and $\left[{ }^{18} \mathrm{O}\right]$-QUIN were detected as the intact molecular anion rather than a low molecular weight fragment. Accuracy was obtained with $\left[{ }^{18} \mathrm{O}\right]-$ QUIN as internal standard rather than structural isomers or chemical analogs of QUIN. $\left[{ }^{18} \mathrm{O}\right]-\mathrm{QUIN}$ is chemically identical to QUIN, elutes from the chromatography system at the same time as QUIN, and has a small mass displacement that is sufficient to avoid the need to correct for naturally occurring isotopes. Samples or individual brain areas from each experiment were run within the same assay with a standard curve. The results presented in Table 2 were obtained by the original method $(20$, 21) and a Kratos MS-80 magnetic sector mass spectrometer. The remaining results were obtained with the following modifications using a Hewlett-Packard 5988A mass spectrometer (HewlettPackard Co., Palo Alto, CA). Brain samples were placed in preweighted $1.5-\mathrm{mL}$ polypropylene tubes, frozen in dry ice, and reweighed. Brain samples were sonicated in $1 \mathrm{~mL}$ of $3 \mathrm{M}$ hydrochloric acid containing 9 pmol of $\left[{ }^{18} \mathrm{O}\right]-\mathrm{QUIN}$ and centrifuged, and $800 \mu \mathrm{L}$ of the supernatant were mixed with $1 \mathrm{~mL}$ of water. QUIN standards $(0-25 \mathrm{ng})$ were dissolved in $800 \mu \mathrm{L}$ of water and mixed with the same hydrochloric acid $/\left[{ }^{18} \mathrm{O}\right]-\mathrm{QUIN}$ solution. Brain samples and standards were washed with $3 \mathrm{~mL}$ of chloroform, and the aqueous layer was collected. CSF $(50 \mu \mathrm{L})$, plasma $(10 \mu \mathrm{L})$, and QUIN standards dissolved in water (50 or $10 \mu \mathrm{L}$ ) were mixed with deionized water containing $9 \mathrm{pmol}$ of $\left[{ }^{18} \mathrm{O}\right]-Q U I N$. All samples were freeze-dried overnight. QUIN and $\left[{ }^{18} \mathrm{O}\right]-Q U I N$ were esterified to their dihexafluoroisopropanol esters with complete retention of the isotope and extracted into $300-400 \mu \mathrm{L}$ of heptane over $250 \mu \mathrm{L}$ of water. Heptane extracts $(1-2 \mu \mathrm{L})$ were injected directly into a $1 \mathrm{~m} \times 0.53 \mathrm{~mm}$ inner diameter fused silica precolumn at $80^{\circ} \mathrm{C}$ attached to a $15 \times 0.25$ mm inner diameter DB-5 analytical capillary column, run isothermal at $114^{\circ} \mathrm{C}$ with helium as carrier gas. Transfer line and ion source were set at $175^{\circ} \mathrm{C}$ with methane as reagent gas at $0.5 \mathrm{~mm}$ $\mathrm{Hg}$. QUIN and $\left[{ }^{18} \mathrm{O}\right]-\mathrm{QUIN}$ were monitored at $\mathrm{m} / \mathrm{z} 467$ and 471 , respectively, and quantified as peak areas. Normal values for brain QUIN concentrations using this method consistently give brain QUIN concentrations substantially lower than those reported for the rat as determined by the electron capture mass spectrometric method. The level of QUIN in cortex is $36 \pm 7$ $\mathrm{fmol} / \mathrm{mg}$ of tissue measured with this method (20). Comparable standard deviations are also obtained in other brain regions (20). 
Table 1. Effects of ammonium acetate injection on CSF QUIN and cortical Trp, 5-HIAA, and QUIN*

\begin{tabular}{lcccccc}
\hline & Ammonium & Sodium & & & \multicolumn{2}{c}{ ANOVA significance } \\
\cline { 3 - 7 } & acetate & acetate & Saline & SD & $\begin{array}{c}\text { Ammonium acetate } \\
\text { vs saline }\end{array}$ & $\begin{array}{c}\text { Ammonium acetate } \\
v s \text { sodium acetate }\end{array}$ \\
\hline CSF QUIN (nM) & 27 & 28 & 39 & 15 & NS & NS \\
Cortical Trp (pmol/mg) & 64 & 58 & 56 & 18 & NS & NS \\
Cortical 5-HIAA (pmol/mg) & 1.6 & 1.1 & 1.0 & 0.46 & $<0.05$ & $<0.05$ \\
Cortical QUIN (fmol/mg) & 40 & 35 & 38 & 14 & NS & NS \\
\hline
\end{tabular}

* Animals were injected with ammonium acetate $(7 \mathrm{mmol} / \mathrm{kg})$, sodium acetate $(7 \mathrm{mmol} / \mathrm{kg})$, or saline. One $\mathrm{h}$ later, CSF and cortex were harvested for analysis of 5-HIAA, Trp, and QUIN. Values represent the mean of at least seven independent observations. The overall variance is given. ANOVA, analysis of variance.

Table 2. Effects of urease infusion on levels of brain QUIN*

\begin{tabular}{|c|c|c|c|c|c|c|c|}
\hline \multirow[b]{2}{*}{ Region } & \multirow[b]{2}{*}{ Group } & \multirow[b]{2}{*}{$\operatorname{Trp}(-)$} & \multirow[b]{2}{*}{$\operatorname{Trp}(+)$} & \multirow[b]{2}{*}{ SD } & \multicolumn{3}{|c|}{ ANOVA significance } \\
\hline & & & & & Urease & Trp & Urease $\times$ Trp \\
\hline Frontal cortex & $\begin{array}{l}\text { Sham } \\
\text { Urease }\end{array}$ & $\begin{array}{l}60 \\
68\end{array}$ & $\begin{array}{l}358 \\
250\end{array}$ & 106 & NS & $<0.001$ & NS \\
\hline Pariatal certer & Urease & $\begin{array}{l}68 \\
57\end{array}$ & $\begin{array}{l}250 \\
689\end{array}$ & & & & \\
\hline Parietal cortex & $\begin{array}{l}\text { Sham } \\
\text { Urease }\end{array}$ & $\begin{array}{l}57 \\
48\end{array}$ & $\begin{array}{l}689 \\
250\end{array}$ & 128 & $<0.002$ & $<0.001$ & $<0.002$ \\
\hline Striatum & $\begin{array}{l}\text { Sham } \\
\text { Urease }\end{array}$ & $\begin{array}{l}21 \\
16\end{array}$ & $\begin{array}{r}207 \\
47\end{array}$ & 78 & $<0.05$ & $<0.01$ & $<0.05$ \\
\hline Thalamus & $\begin{array}{l}\text { Sham } \\
\text { Urease }\end{array}$ & $\begin{array}{l}41 \\
28\end{array}$ & $\begin{array}{r}173 \\
97\end{array}$ & 52 & $<0.05$ & $<0.001$ & NS \\
\hline Hippocampus & $\begin{array}{l}\text { Sham } \\
\text { Urease }\end{array}$ & $\begin{array}{l}27 \\
25\end{array}$ & $\begin{array}{l}168 \\
117\end{array}$ & 38 & NS & $<0.001$ & NS \\
\hline
\end{tabular}

* Urease-infused and sham-operated control animals were injected with $\operatorname{Trp}(200 \mathrm{mg} / \mathrm{kg}$ intraperitoneally $)$, designated $\operatorname{Trp}(+)$, or saline, designated $\operatorname{Trp}(-), 46 \mathrm{~h}$ after surgery. At $48 \mathrm{~h}$ after surgery, blood and brain tissue were harvested for analysis of plasma Trp and brain biogenic amines and their metabolites (see Table 4) and for the analysis of QUIN ( $\mathrm{fmol} / \mathrm{mg}$ of tissue). Values represent the mean of at least six independent observations. The overall variance is given. ANOVA, analysis of variance.

Statistical Analyses. Sample size determinations were based on the reported variance for the measurement of QUIN (see above) and the previous observation that cortical QUIN was elevated $70 \%$ in hepatic encephalopathy and $60 \%$ in ammonium acetate-injected rats (4). This would indicate at least a 2-SD elevation. Sample sizes used in this study of five to eight per group yield a power of $80-95 \%$ for the detection of this difference with $\alpha=0.05$ (two-tailed $t$ test). The data presented in Table 3 were compared by analysis of variance using SAS (SAS Institute, Inc., Cary, NC); the other data were compared by analysis of variance using a Statview 512+ on an Apple Macintosh.

\section{RESULTS}

Time course of urease. Because the neurologic effects of hyperammonemia appear to be related to its duration, the effects of urease infusion on the levels of biogenic amines and amino acids were examined over time. Table 3 summarizes the changes in biogenic amines, Trp, and QUIN in cortex during the $48 \mathrm{~h}$ after urease infusion. Plasma ammonium levels increased 7 -fold within $12 \mathrm{~h}$ (normal levels were $193 \mu \mathrm{M}$ ), 4.5 -fold at $24 \mathrm{~h}$, and 3.0-fold at $48 \mathrm{~h}$ (mean of six observations at each time point, data not shown). From 12 to $48 \mathrm{~h}$, levels of Trp in urease-infused rats were $100 \%$ elevated compared to sham controls. There were $50 \%$ increases in 5-HIAA. Serotonin levels were significantly elevated at $48 \mathrm{~h}$. Urease infusion had no significant effects on QUIN, norepinephrine, or dopamine. Cortical amino acids were also measured (Table 3 ). In the urease-infused animals, glutamine was most elevated (3-fold, $p<0.0001$ ). There were also significant increases in proline, tyrosine, phenylalanine, histidine, lysine, and arginine. No significant changes were observed in other amino acids.

Effect of urease and Trp infusion on biogenic amines, Trp, and $Q U I N$. In an attempt to accentuate possible differences in Trp metabolism in the urease-infused rat, either $\operatorname{Trp}(200 \mathrm{mg} / \mathrm{kg})$ or saline was injected intraperitoneally $46 \mathrm{~h}$ after implanting the urease-containing pump. The levels of brain biogenic amines and QUIN were measured in animals killed $2 \mathrm{~h}$ after injection of Trp. Table 4 shows that both free and total Trp in plasma increased 3- to 4-fold after Trp injection, but that there was no difference between urease-infused and sham animals. As observed in the first study (Table 3), urease infusion caused increases in Trp, 5-HIAA, and serotonin in cortex (Table 4). Norepinephrine was not affected. Although Trp infusion resulted in further increases of Trp and 5-HIAA, serotonin and norepinephrine levels did not change (Table 4). 3-Hydroxykynurenine, one of the intermediates from Trp to QUIN, was elevated after Trp infusion. There were no significant statistical interactions between Trp and urease infusion.

QUIN was measured in multiple brain regions of these animals (Table 2). Although Trp infusion resulted in at least 3-fold increases of QUIN in all regions in both urease-infused rats and sham controls $(p<0.01)$, urease infusion alone had no effect on QUIN levels. In fact, Trp $(+)$ /urease-infused animals had lower levels of QUIN in striatum, thalamus, and parietal cortex than did the $\operatorname{Trp}(+) /$ sham animals $(p<0.05)$. There was significant interaction between urease infusion and Trp injections in both parietal cortex and striatum.

Levels of 5-HIAA and QUIN in CSF. The levels of QUIN in plasma are 8-fold higher than the levels of QUIN in brain tissue (20). The negative findings of our study, coupled with the observation of high QUIN in plasma, prompted the concern that the blood left in brain tissue masked increases of QUIN. To control for this theoretical contamination, another group of animals was injected with Trp $(50 \mathrm{mg} / \mathrm{kg}) 46 \mathrm{~h}$ after implant of the ureasecontaining pumps. Two $h$ later, the animals were anesthetized and CSF was removed. The levels of 5-HIAA and QUIN in CSF and the levels of QUIN in plasma were measured (Table 5). Even though Trp injection resulted in a marked increase in the concentration of QUIN in both CSF and plasma, urease had no effect on QUIN values in CSF. As was seen with brain tissue, urease infusion increased the levels of 5-HIAA in CSF. There 
Table 3. Effects of urease infusion on cortical biogenic amines, QUIN, and amino acids at 12, 24, and $48 h^{*}$

\begin{tabular}{|c|c|c|c|c|c|c|c|c|}
\hline & \multirow[b]{2}{*}{ Group } & \multicolumn{3}{|c|}{ Time (h) } & \multirow[b]{2}{*}{ SD } & \multicolumn{3}{|c|}{ ANOVA significance } \\
\hline & & 12 & 24 & 48 & & Urease & Time & Urease $\times$ time \\
\hline Trp & $\begin{array}{l}\text { Sham } \\
\text { Urease }\end{array}$ & $\begin{array}{l}27.6 \\
55.1\end{array}$ & $\begin{array}{l}22.3 \\
54.5\end{array}$ & $\begin{array}{l}27.2 \\
51.1\end{array}$ & 8.2 & $<0.001$ & NS & NS \\
\hline Serotonin & $\begin{array}{l}\text { Sham } \\
\text { Urease }\end{array}$ & $\begin{array}{l}0.84 \\
0.83\end{array}$ & $\begin{array}{l}0.63 \\
0.69\end{array}$ & $\begin{array}{l}0.65 \\
0.91\end{array}$ & 0.14 & $<0.05$ & $<0.05$ & NS \\
\hline 5-HIAA & $\begin{array}{l}\text { Sham } \\
\text { Urease }\end{array}$ & $\begin{array}{l}1.18 \\
1.51\end{array}$ & $\begin{array}{l}0.96 \\
1.36\end{array}$ & $\begin{array}{l}1.02 \\
1.64\end{array}$ & 0.26 & $<0.001$ & NS & NS \\
\hline QUIN & $\begin{array}{l}\text { Sham } \\
\text { Urease }\end{array}$ & $\begin{array}{l}17.8 \\
18.4\end{array}$ & $\begin{array}{l}17.6 \\
22.5\end{array}$ & $\begin{array}{l}25.2 \\
25.3\end{array}$ & 7.6 & NS & NS & NS \\
\hline Dopamine & $\begin{array}{l}\text { Sham } \\
\text { Urease }\end{array}$ & $\begin{array}{l}1.31 \\
1.02\end{array}$ & $\begin{array}{l}1.00 \\
1.28\end{array}$ & $\begin{array}{l}1.32 \\
1.02\end{array}$ & 0.48 & NS & NS & NS \\
\hline Norepinephrine & $\begin{array}{l}\text { Sham } \\
\text { Urease }\end{array}$ & $\begin{array}{l}0.94 \\
0.79\end{array}$ & $\begin{array}{l}0.67 \\
0.67\end{array}$ & $\begin{array}{l}0.74 \\
0.78\end{array}$ & 0.15 & NS & $<0.05$ & NS \\
\hline Alanine & $\begin{array}{l}\text { Sham } \\
\text { Urease }\end{array}$ & $\begin{array}{l}0.66 \\
0.69\end{array}$ & $\begin{array}{l}0.63 \\
0.75\end{array}$ & $\begin{array}{l}0.68 \\
0.74\end{array}$ & 0.15 & NS & NS & NS \\
\hline Arginine & $\begin{array}{l}\text { Sham } \\
\text { Urease }\end{array}$ & $\begin{array}{l}0.104 \\
0.136\end{array}$ & $\begin{array}{l}0.116 \\
0.154\end{array}$ & $\begin{array}{l}0.126 \\
0.146\end{array}$ & 0.037 & $<0.05$ & NS & NS \\
\hline Aspartate & $\begin{array}{l}\text { Sham } \\
\text { Urease }\end{array}$ & $\begin{array}{l}2.54 \\
2.41\end{array}$ & $\begin{array}{l}2.98 \\
2.19\end{array}$ & $\begin{array}{l}2.86 \\
2.38\end{array}$ & 0.76 & NS & NS & NS \\
\hline Glutamate & $\begin{array}{l}\text { Sham } \\
\text { Urease }\end{array}$ & $\begin{array}{l}8.1 \\
7.7\end{array}$ & $\begin{array}{l}8.6 \\
7.8\end{array}$ & $\begin{array}{l}8.5 \\
7.7\end{array}$ & 1.9 & NS & NS & NS \\
\hline Glutamine & $\begin{array}{l}\text { Sham } \\
\text { Urease }\end{array}$ & $\begin{array}{r}4.4 \\
12.5\end{array}$ & $\begin{array}{r}4.3 \\
14.8\end{array}$ & $\begin{array}{r}4.5 \\
13.5\end{array}$ & 2.6 & $<0.001$ & NS & NS \\
\hline Histidine & $\begin{array}{l}\text { Sham } \\
\text { Urease }\end{array}$ & $\begin{array}{l}0.160 \\
0.258\end{array}$ & $\begin{array}{l}0.136 \\
0.242\end{array}$ & $\begin{array}{l}0.156 \\
0.248\end{array}$ & 0.068 & $<0.001$ & NS & NS \\
\hline Isoleucine & $\begin{array}{l}\text { Sham } \\
\text { Urease }\end{array}$ & $\begin{array}{l}0.058 \\
0.050\end{array}$ & $\begin{array}{l}0.060 \\
0.068\end{array}$ & $\begin{array}{l}0.076 \\
0.074\end{array}$ & 0.029 & NS & NS & NS \\
\hline Leucine & $\begin{array}{l}\text { Sham } \\
\text { Urease }\end{array}$ & $\begin{array}{l}0.170 \\
0.166\end{array}$ & $\begin{array}{l}0.174 \\
0.266\end{array}$ & $\begin{array}{l}0.226 \\
0.220\end{array}$ & 0.086 & NS & NS & NS \\
\hline Lysine & $\begin{array}{l}\text { Sham } \\
\text { Urease }\end{array}$ & $\begin{array}{l}0.198 \\
0.246\end{array}$ & $\begin{array}{l}0.174 \\
0.234\end{array}$ & $\begin{array}{l}0.214 \\
0.240\end{array}$ & 0.055 & $<0.05$ & NS & NS \\
\hline Methionine & $\begin{array}{l}\text { Sham } \\
\text { Urease }\end{array}$ & $\begin{array}{l}0.074 \\
0.088\end{array}$ & $\begin{array}{l}0.11 \\
0.132\end{array}$ & $\begin{array}{l}0.11 \\
0.130\end{array}$ & 0.03 & NS & $<0.05$ & NS \\
\hline Phenylalanine & $\begin{array}{l}\text { Sham } \\
\text { Urease }\end{array}$ & $\begin{array}{l}0.130 \\
0.180\end{array}$ & $\begin{array}{l}0.124 \\
0.220\end{array}$ & $\begin{array}{l}0.178 \\
0.190\end{array}$ & 0.062 & $<0.05$ & NS & NS \\
\hline Proline & $\begin{array}{l}\text { Sham } \\
\text { Urease }\end{array}$ & $\begin{array}{l}0.094 \\
0.104\end{array}$ & $\begin{array}{l}0.088 \\
0.128\end{array}$ & $\begin{array}{l}0.098 \\
0.142\end{array}$ & 0.033 & $<0.05$ & NS & NS \\
\hline Tyrosine & $\begin{array}{l}\text { Sham } \\
\text { Urease }\end{array}$ & $\begin{array}{l}0.142 \\
0.170\end{array}$ & $\begin{array}{l}0.136 \\
0.214\end{array}$ & $\begin{array}{l}0.162 \\
0.212\end{array}$ & 0.049 & $<0.01$ & NS & NS \\
\hline
\end{tabular}

* Animals were implanted with osmotic minipumps or sham tubing as described in Materials and Methods. Cortex was dissected at 12, 24, and $48 \mathrm{~h}$ after surgery. The levels of biogenic amines (pmol/mg tissue), Trp (pmol/mg tissue), QUIN (fmol/mg tissue), and other amino acids ( $\mathrm{nmol} /$ $\mathrm{mg}$ tissue) were measured in cerebral cortex. No significant changes were observed in taurine, threonine, serine, glycine, citrulline, cystine, valine, or ornithine. Data were compared by analysis of variance (ANOVA). Values represent the mean of five independent observations. The overall variance is given.

was a direct linear correlation between plasma and CSF QUIN $\left(r^{2}=0.92, p<0.001\right)$.

QUIN in brain and CSF of animals injected with ammonium acetate. In a previous study, Moroni et al. (4) reported increased cortical QUIN levels and 5-HIAA after ammonium acetate injection. In our final study, rats were injected with ammonium acetate to stimulate an increase in QUIN. Plasma, CSF, and cortical tissue were obtained $1 \mathrm{~h}$ after injection with ammonium acetate $(7 \mathrm{mmol} / \mathrm{kg}$ ) (Table 1$)$. At $1 \mathrm{~h}$ after injection, plasma ammonium was elevated to twice that of control (control $=140$ $\mu \mathrm{M}, p<0.05$ ). As seen in the urease-infused rat, ammonium acetate injection caused a significant increase in brain 5-HIAA, but had no effect on QUIN levels in plasma, CSF, or cortex.

\section{DISCUSSION}

Trp is metabolized to both serotonin and QUIN (Fig. 1) QUIN has agonist activity at the NMDA subclass of excitatory amino acid receptors (for reviews see 5, 6). Excessive activation of these receptors by QUIN or other NMDA receptor agonists results in neurodegeneration. These receptors have been associated with such normal brain processes as regulation of synapto- genesis and long term potentiation (for reviews see 5,6 ). In a portocaval shunted rat, Moroni et al. (4) documented increased levels of QUIN in cerebral cortex (1.7-fold), but no changes in hippocampus, caudate, or brainstem. After ammonium acetate injection, this same group observed increased QUIN (1.6-fold) in cerebral cortex. The levels of QUIN in blood and CSF were not determined in either study. We have documented 2- to 10fold increases of QUIN in CSF of comatose children and 2- to 4-fold increases of QUIN in CSF of clinically stable children with congenital hyperammonemia (11). Previous studies have also documented increased levels of the serotonin metabolite, 5HIAA, in CSF and/or brain of children with congenital hyperammonemia, adults with hepatic encephalopathy, and animal models of these diseases $(7,8,22-24)$. Some studies $(9,10)$ suggest that augmented transport of Trp into the CNS leads to this increase in serotonin turnover (Fig. 1).

The goal of the present studies was to examine the relationship between plasma ammonium levels and QUIN in brain and CSF of rat models of hyperammonemia. We chose animal models that simulated urea cycle disorders in causing hyperammonemia in the absence of liver damage. Previous studies have docu- 
Table 4. Effects of urease infusion on levels of plasma and cortical Trp and on cortical biogenic amines and metabolites*

\begin{tabular}{|c|c|c|c|c|c|c|c|}
\hline & & \multirow[b]{2}{*}{$\operatorname{Trp}(-)$} & \multirow[b]{2}{*}{$\operatorname{Trp}(+)$} & \multirow[b]{2}{*}{ SD } & \multicolumn{3}{|c|}{ ANOVA significance } \\
\hline & & & & & Urease & Trp & Urease $\times$ Trp \\
\hline Free plasma Trp & $\begin{array}{l}\text { Sham } \\
\text { Urease }\end{array}$ & $\begin{array}{l}84 \\
99\end{array}$ & $\begin{array}{l}287 \\
251\end{array}$ & 82 & NS & $<0.001$ & NS \\
\hline Total plasma Trp & $\begin{array}{l}\text { Sham } \\
\text { Urease }\end{array}$ & $\begin{array}{l}13 \\
13\end{array}$ & $\begin{array}{l}50 \\
54\end{array}$ & 7 & NS & $<0.001$ & NS \\
\hline Cortical Trp & $\begin{array}{l}\text { Sham } \\
\text { Urease }\end{array}$ & $\begin{array}{l}35 \\
70\end{array}$ & $\begin{array}{l}140 \\
150\end{array}$ & 23 & $<0.01$ & $<0.001$ & NS \\
\hline Cortical 5-HIAA & $\begin{array}{l}\text { Sham } \\
\text { Urease }\end{array}$ & $\begin{array}{l}2.5 \\
4.0\end{array}$ & $\begin{array}{l}3.6 \\
4.5\end{array}$ & 0.81 & $<0.001$ & $<0.01$ & NS \\
\hline Cortical serotonin & $\begin{array}{l}\text { Sham } \\
\text { Urease }\end{array}$ & $\begin{array}{l}0.95 \\
1.5\end{array}$ & $\begin{array}{l}1.27 \\
2.1\end{array}$ & 0.98 & $<0.05$ & NS & NS \\
\hline $\begin{array}{l}\text { Cortical 3-hydroxykynu- } \\
\text { renine }\end{array}$ & $\begin{array}{l}\text { Sham } \\
\text { Urease }\end{array}$ & $\begin{array}{l}0.15 \\
0.14\end{array}$ & $\begin{array}{l}0.31 \\
0.37\end{array}$ & 0.19 & NS & $<0.01$ & NS \\
\hline Cortical norepinephrine & $\begin{array}{l}\text { Sham } \\
\text { Urease }\end{array}$ & $\begin{array}{l}1.24 \\
1.63\end{array}$ & $\begin{array}{l}1.28 \\
1.41\end{array}$ & 0.50 & NS & NS & NS \\
\hline
\end{tabular}

* Urease-infused and sham-operated control animals were injected with $\operatorname{Trp}(200 \mathrm{mg} / \mathrm{kg}$ intraperitoneally), designated $\operatorname{Trp}(+)$, or saline, designated $\operatorname{Trp}(-), 46 \mathrm{~h}$ after surgery. At $48 \mathrm{~h}$ after surgery, blood and brain tissue were harvested for analysis of plasma Trp $(\mu \mathrm{M})$ and brain Trp, biogenic amines, and their metabolites ( $\mathrm{pmol} / \mathrm{mg}$ tissue). Values represent the mean of six independent observations. The overall variance is given. ANOVA, analysis of variance.

Table 5. Effects of urease infusion on levels of CSF QUIN, CSF 5-HIAA, and plasma QUIN*

\begin{tabular}{|c|c|c|c|c|c|c|c|}
\hline & & \multirow[b]{2}{*}{$\operatorname{Trp}(-)$} & \multirow[b]{2}{*}{$\operatorname{Trp}(+)$} & \multirow[b]{2}{*}{ SD } & \multicolumn{3}{|c|}{ ANOVA significance } \\
\hline & & & & & Urease & Trp & Urease $\times$ Trp \\
\hline Plasma QUIN (nM) & $\begin{array}{l}\text { Sham } \\
\text { Urease }\end{array}$ & $\begin{array}{l}260 \\
360\end{array}$ & $\begin{array}{l}11500 \\
12900\end{array}$ & 7800 & NS & $<0.001$ & NS \\
\hline CSF QUIN (nM) & $\begin{array}{l}\text { Sham } \\
\text { Urease }\end{array}$ & $\begin{array}{l}14.2 \\
15.2\end{array}$ & $\begin{array}{l}399 \\
392\end{array}$ & 204 & NS & $<0.001$ & NS \\
\hline CSF 5-HIAA (nM) & $\begin{array}{l}\text { Sham } \\
\text { Urease }\end{array}$ & $\begin{array}{l}0.60 \\
1.26\end{array}$ & $\begin{array}{l}1.19 \\
1.88\end{array}$ & 0.36 & $<0.001$ & $<0.001$ & NS \\
\hline
\end{tabular}

* Urease-infused and sham-operated control animals were injected with $\operatorname{Trp}(200 \mathrm{mg} / \mathrm{kg}$ intraperitoneally), designated Trp $(+)$, or saline, designated Trp(-), $46 \mathrm{~h}$ after surgery. At $48 \mathrm{~h}$ after surgery, blood and CSF were harvested for analysis of QUIN and 5-HIAA. Values represent the mean of six independent observations. The overall variance is given. ANOVA, analysis of variance.

mented the use of urease infusion as a model of congenital hyperammonemia (12). To maximize alterations in brain metabolism, the dose was doubled in the current studies. At this dose, there was a $20 \%$ mortality rate. Most animals experienced periods of ataxia and occasional tonic-clonic seizures. The levels of brain Trp were approximately 2-fold elevated, and the levels of serotonin and 5-HIAA were significantly elevated (Table 3 ). Despite large increases in the levels of Trp and some of its metabolites, we were unable to document an effect of urease on the levels of QUIN in frontal cortex (Table 3), parietal cortex, striatum, thalamus, and hippocampus (Table 2).

The levels of QUIN observed in the current study are almost 50 -fold lower than those previously reported by Moroni et al. (4) but are similar to those consistently reported by a coauthor of the present study (M.P.H.) $(20,21,25,26)$. In more recent studies by Moroni et al. (27), the levels of QUIN are only approximately 7 -fold higher than those reported in the current study. The reason for these discrepancies is not clear, but it may be related to the fact that, in all of the studies by Heyes and the recent studies by Moroni et al. (27), $\left[{ }^{18} \mathrm{O}\right]-Q U I N$ was used as an internal standard, and a structural analog of QUIN was used as an internal standard in the earlier studies of Moroni et al. (4).

The maximum change in biogenic amines was observed at 48 $h$ after implant. To capitalize on this, we explored the effects of urease infusion on the levels of brain QUIN at $48 \mathrm{~h}$. Trp injections were combined with urease infusion in an attempt to accentuate changes in QUIN. At $46 \mathrm{~h}$ post implant, animals received injections of either Trp or saline and were killed $2 \mathrm{~h}$ later. Whereas the Trp injection resulted in a substantial increase in the levels of Trp, 5-HIAA, 3-hydroxykynurenine, and QUIN in cortex, the levels of QUIN were not elevated to a greater extent in the urease-infused animals than in the controls (Tables 2 and 4$)$.

We were concerned that, because the levels of QUIN are 8fold higher in blood than in brain (20), it was possible that any changes in brain QUIN might have been masked by the presence of blood in brain tissue. To control for this, the effects of urease infusion combined with Trp injections on the levels of plasma QUIN, CSF QUIN, and CSF 5-HIAA were examined (Table 5). As observed in brain tissue, urease infusion elevated the levels of 5-HIAA in CSF, but had no effect on the levels of QUIN in CSF or plasma. L-Trp administration increased both plasma and CSF QUIN levels to the same degree in sham and urease-infused animals.

We then attempted to replicate the findings of increased QUIN in the brains of animals acutely injected with ammonium acetate (4). As seen with the urease-infused animals, ammonium acetate injection elevated 5-HIAA levels in brain to levels above control but did not affect QUIN levels in either CSF or brain. This observation suggests that neither the synthesis of QUIN in brain nor the diffusion of QUIN across the blood brain barrier are increased by hyperammonemia. It is possible, however, that increases in QUIN may have been attenuated by increased catabolism by quinolinic acid phosphoribosyltransferase, the enzyme that metabolizes QUIN.

These data, together with our observations of increased QUIN in children with congenital hyperammonemia (11), suggest that the regulation of the synthesis or degradation of QUIN may be different in humans than in these rat models of hyperammonemia. A possible explanation for this discrepancy involves the regulation of indoleamine-2,3-dioxygenase, the first enzyme in the pathway for the conversion of Trp to QUIN (Fig. 1). The 
activity of this enzyme is increased in brain and other extrahepatic tissues after immune stimulation and brain injury $(25,26)$, and there is evidence that rats have a relatively low responsiveness (28). Therefore, in man, hyperammonemia may lead to increased levels of brain QUIN after up-regulation of indoleamine-2,3dioxygenase activity, secondary to inflammatory responses within the CNS.

In summary, two animal models were used in an attempt to develop an animal model with a hyperammonemia-induced elevation in brain QUIN. We and others have not observed irreversible neuronal damage with urease-infused rats or mice (29, unpublished observations). It is not clear if the lack of damage is related to a lack of an increase in QUIN or to the duration of hyperammonemia. A rat may have to be kept alive and in coma for prolonged periods of time to induce neuropathology as is observed in children with congenital hyperammonemia. Despite evidence for increased Trp metabolism to serotonin and 5-HIAA, we did not observe increases in QUIN in either the urease-infused rat or the ammonium acetate-injected rat. As a result, the demonstration of a role for QUIN in hyperammonemia-induced brain damage will require either the use of tissues from children who do not survive hyperammonemic coma or the development of other animal models.

Acknowledgments. The authors thank Shirley Quaskey for her help with the statistics and Katherine Gorry-Hines for help with editing this manuscript.

\section{REFERENCES}

1. Batshaw ML 1984 Hyperammonemia. Curr Probl Pediatr 14:1-69

2. Msall M, Monahan PS, Chapanis N, Batshaw ML 1988 Cognitive development in children with inborn errors of urea synthesis. Acta Paediatr Jpn 30:435441

3. Moroni F, Lombardi G. Carla V, Lal S, Etienne P, Nair NPV 1986 Increase in the content of quinolinic acid in cerebrospinal fluid and frontal cortex of patients with hepatic failure. J Neurochem 47:1667-1671

4. Moroni F, Lombardi G. Carla V, Pellegrini D. Carassale GL. Cortesini C 1986 Content of quinolinic acid and of other tryptophan metabolites increases in brain regions of rats used as experimental models of hepatic encephalopathy. J Neurochem 46:869-874

5. Robinson MB, Coyle JT 1987 Glutamate and related acidic excitatory neurotransmitters: from basic science to clinical application. FASEB J 1:446-455

6. McDonald JW, Johnston MV 1990 Physiological and pathophysiological roles of excitatory amino acids during central nervous system development. Brain Res Rev 15:41-70

7. Hyman SL, Coyle JT, Parke JC, Poter C, Thomas GC, Jankel W, Batshaw ML 1986 Anorexia and altered serotonin metabolism in a patient with argininosuccinic aciduria. J Pediatr 108:705-709

8. Hyman SL, Porter CA, Page TJ, Iwata BA, Kissel PR, Batshaw ML 1987 Behavioral management of feeding disturbances in urea cycle and organic acid disorders. J Pediatr 111:558-562

9. Bachmann C. Colombo JP 1983 Increased tryptophan uptake into the brain in hyperammonemia. Life Sci 33:2417-2424
10. Mans AM, Biebuyck JF, Shelly K, Hawkins RA 1982 Regional blood-brain barrier permeability to amino acids after portocaval anastomosis. J Neurochem 38:705-717

11. Batshaw ML, Heyes M, Djali S, Rorke LB, Robinson MB 1990 Quinolinate, a possible neurotoxin in children with congenital hyperammonemia. Pediatr Res 27:188A(abstr)

12. Batshaw ML, Hyman SL, Mellits ED, Thomas GH, DeMuro R, Coyle JT 1986 Behavioral and neurotransmitter changes in the urease-infused rat: a model of congenital hyperammonemia. Pediatr Res 20:1310-1315

13. Rogers QR. Harper AE 1965 Amino acid diets and maximal growth in the rat. J Nutr 87:267-273

14. Glowinski J, Iverson LL 1966 Regional studies of catecholamines in the rat brain. I. The disposition of $\left[{ }^{3} \mathrm{H}\right]$ dopamine and $\left[{ }^{3} \mathrm{H}\right] D O P A$ in various regions of the brain. J Neurochem 13:655-669

15. Heyes MP, Quearry BJ 1990 Quantification of kynurenic acid in cerebrospinal fluid: effects of systemic and central L-kynurenine. J Chromatogr 530:108115

16. Deshmukh DR, Singh KR, Meert K, Deshmukh GD 1990 Failure of Lcarnitine to protect mice against hyperammonemia induced by ammonium acetate or urease injection. Pediatr Res 28:256-260

17. Nazer BL, Schoolwerth AC 1979 An improved microfluorometric enzymatic assay for the detection of ammonia. Anal Biochem 95:507-511

18. Anderson GM, Young JG, Batter DK, Young SN, Cohen DJ, Shaywitz BA 1981 Determination of indoles and catechols in rat brain and pineal using liquid chromatography with fluorometric and amperometric detection. J Chromatogr 223:315-320

19. Zaczek R, Coyle JT 1982 Rapid and simple method for measuring biogenic amines and metabolites in brain homogenates by HPLC-electrochemical detection. J Neural Transm 53:1-5

20. Heyes MP Markey SP 1988 Quantification of quinolinic acid in rat brain. whole blood, and plasma by gas chromatography and negative chemical ionization mass spectrometry: effects of systemic L-tryptophan administration on brain and blood quinolinic acid concentrations. Anal Biochem 174:349-359

21. Heyes MP. Markey SP $1988\left[{ }^{18} \mathrm{O}\right]-\mathrm{Quinolinic}$ acid: its esterification without back exchange for use as internal standard in the quantitation of brain and CSF quinolinic acid. Biomed Environ Mass Spectrom 15:291-293

22. Bachmann C, Colombo JP 1984 Increase of tryptophan and 5-hydroxyindole acetic acid in the brain of ornithine carbamyltransferase deficient sparse-fur mice. Pediatr Res 18:372-375

23. Batshaw ML, Hyman SL, Coyle JT, Robinson MB, Qureshi IA, Mellits ED, Quaskey S 1988 Effect of sodium benzoate and sodium phenylacetate on brain serotonin turnover in the ornithine transcarbamylase-deficient sparsefur mouse. Pediatr Res 23:368-374

24. Bengtsson F, Bugge M, Johansen KH, Butterworth RF 1991 Brain tryptophan hydroxylation in the portocaval shunted rat: a hypothesis for the regulation of serotonin turnover in vivo. J Neurochem 56:1069-1074

25. Saito K, Markey SP. Heyes MP 1991 Chronic effects of gamma-interferon on quinolinic acid and indoleamine-2,3-dioxygenase in brain of C57BL6 mice. Brain Res 546:151-154

26. Saito K, Nowak TS, Markey SP, Heyes MP 1991 Induction of indoleamine2,3-dioxygenase activity and increased quinolinic acid in brain following transient ischemia in the gerbil. Amino Acids 1:135(abstr)

27. Moroni F, Russi P. Gallo-Mezo MA. Moneti G. Pellicciari R 1991 Modulation of quinolinic and kynurenic acid content in rat brain: effects of endotoxins and nicotinylalanine. J Neurochem 57:1630-1635

28. Daley-Yates PT, Powell AP, Smith LL 1988 Pulmonary indoleamine 2.3dioxygenase activity and its significance in the response of rats, mice, and rabbits to oxidative stress. Toxicol Appl Pharmacol 96:222-232

29. Gibson GE, Zimber A. Krook L, Richardson EP, Visek WJ 1974 Brain histology and behavior of mice injected with urease. J Neuropathol Exp Neurol 33:201-211 